\title{
Physico-chemical parameters and Ichthyofauna diversity of Arasalar estuary in southeast coast of India
}

\author{
C. Raju • G. Sridharan · P. Mariappan • \\ G. Chelladurai
}

Received: 24 October 2014/ Accepted: 19 December 2014/Published online: 7 January 2015

(C) The Author(s) 2015. This article is published with open access at Springerlink.com

\begin{abstract}
The physico-chemical changes may have the tendency to accumulate in the various organs of estuarine organisms, especially fish which may in turn enter into the human metabolism through consumption causing serious hazards. Hence, the present study was carried out to determine the physico-chemical characteristics of water and Ichthyofauna in Arasalar estuary in southeast coast of India for the period of 1 year during September 2012August 2013. The environmental parameters such as, temperature, $\mathrm{pH}$, salinity, DO, silicate, nitrate and phosphate were observed from Department of Zoology, Rajah Serfoji Goverment College, Thanjavur, Tamil Nadu, India. During the period of study, air temperature varied from 28.8 to $35^{\circ} \mathrm{C}$. The surface water temperature also varied from 25 to $31.5^{\circ} \mathrm{C}$. The monthly mean values of hydrogen ion concentration of water varied from 7.1 to 8.2. The salinity of water varied from $5.5 \%$ to 34 . Dissolved oxygen in Arasalar estuary was varied from 3.5 to $7.2 \mathrm{mg} / \mathrm{l}$. The total phosphorus varied from 0.29 to $2.15 \mu \mathrm{g} / 1$. The nitrate varied from 0.47 to $3.75 \mu \mathrm{g} / \mathrm{l}$. The silicate content varied from 28.25 to $98.74 \mu \mathrm{g} / \mathrm{l}$. Totally 866 fishes were collected belonging to 4 orders and 5 families. Mystus gulio was found to be the dominant species $(25.40 \%)$ in the study area.
\end{abstract}

C. Raju (凹) · G. Sridharan · P. Mariappan

PG and Research Department of Zoology, Rajash Serfoji

Government College, Thanjavur, Tamilnadu, India

e-mail: raju.zoology@gmail.com

G. Chelladurai

Department of Zoology, Kamaraj College, Tuticorin, Tamilnadu, India

e-mail: chellam.zoo@gmail.com
Keywords Arasalar estuary · Physico-chemical parameters $\cdot$ Ichthyofauna diversity

\section{Introduction}

Estuaries have very high potential for fishery development in the wild and, therefore, are considered as the potential source for feeding, spawning and nursery ground for most of the finfishes and shellfishes. The faunal distribution and productivity of estuary depend on various physico-chemical factors such as temperature, $\mathrm{pH}$, salinity, $\mathrm{DO}$ and micro nutrients such as nitrate, phosphate and silicate. Several investigations have been carried out on the physicochemical features of southeast Indian estuaries and Uppanar estuary (Nedumaran et al. 2011). The fluctuation of physico-chemical characters in estuarine environment has a profound influence on the occurrence of the juveniles of fish stocks. The fish communities of the Australian estuary have been investigated by (Loneragon et al. 1986; Blaber et al. 1989; Morton 1989; Moyle et al. 1986). The Arasalar estuary is located on eastern, side $100 \mathrm{~km}$ away from Rajah Serfoji Government College, Thanjavur, Tamil Nadu, India. It is assumed that the combination of anthropogenic activities and the discharge of domestic sewage into the estuary might influence the biodiversity of the estuarine system. The water quality and biological diversity of this estuarine area are deteriorating, mainly due to rapid increase in human settlement, industrialization and sanitation (Ragothaman and Patil 1995). Few work has been published on the physico-chemical characteristics in relation to ichthyofaunal diversity in Arasalar estuary; hence, the present study was conducted to study the physicochemical parameters and distribution of ichthyofauna in the Arasalar estuary, southeast coast of India. 


\section{Materials and methods}

Study area

Arasalar estuary is situated at Karaikal (Lat. $10^{\circ} 55^{\prime} \mathrm{N}$ and Long. $79^{\circ} 52^{\prime} \mathrm{E}$ ) of the Bay of Bengal, southeast coast of India (Fig. 1). In the present investigation, monthly samplings were carried out from September 2012 to August 2013.

\section{Analysis of physico-chemical parameters}

Water and air temperature was measured using a standard Celsius thermometer with the accuracy of $\pm 0.5^{\circ} \mathrm{C}$. The $\mathrm{pH}$ of water was recorded in the field by using Elico $\mathrm{pH}$ meter (model-LI-120). The Mohr-Knudsen titration procedure and Winkler's method was followed for salinity and dissolved oxygen quantification, respectively (Strickland and Parsons 1972). For analysis of nutrients, surface water samples were collected in clean polyethylene bottles and kept in an ice box and transported immediately to the laboratory. The water samples were filtered using a Millipore filtering system and analyzed for total phosphorus, nitrate and silicate by adopting the standard methods described by (Strickland and Parsons 1972).

\section{Collection and identification of fin fishes from Arasalar} estuary

To estimate the fishery potential, a cast net measuring $2.5 \mathrm{~m}$ length, with a mesh size varying from $7 \mathrm{~mm}$ at the base and $15 \mathrm{~mm}$ at the apex was employed for the collection of fish throughout the period of study. The net was hauled ten times during every collection at each sampling site. The collected specimens were identified up to species level. The fin fishes were identified by using the description and key given by (Day 1889a, b; Nelson 2006).

\section{Results}

Physico-chemical parameters

Monthly variation in meteorological and physico- chemical parameters viz., the correlation coefficient $(r)$ values between the environmental parameters like air and surface water temperature, $\mathrm{pH}$, salinity, dissolved oxygen, phosphate, nitrate and silicate content in Arasalar estuarine water were recorded for a period of 1 year from September 2012 to August 2013 (Table 1). The north east monsoon in Tamil Nadu brings very heavy rain during the October, November and December months. The pattern of rainfall facilitates the divisions of the year into post-monsoon (January-March) summer (April-June) pre-monsoon (July-September) and monsoon (October-December). During the study period, air temperature varied from 28.8 to $35^{\circ} \mathrm{C}$, the minimum was recorded during monsoon season (December 2012) and maximum during the summer season (May 2013) Fig. 2. The surface water temperature varied from 25 to $31.5^{\circ} \mathrm{C}$. The minimum surface water temperature was recorded during monsoon season (November 2012) and maximum was recorded during the summer season (May 2013) Fig. 3. The monthly mean values of hydrogen ion concentration of water varied from 7.1 to 8.2. Maximum values of $\mathrm{pH}$ were observed in the summer season (May 2013) and minimum values were

Fig. 1 Study area map

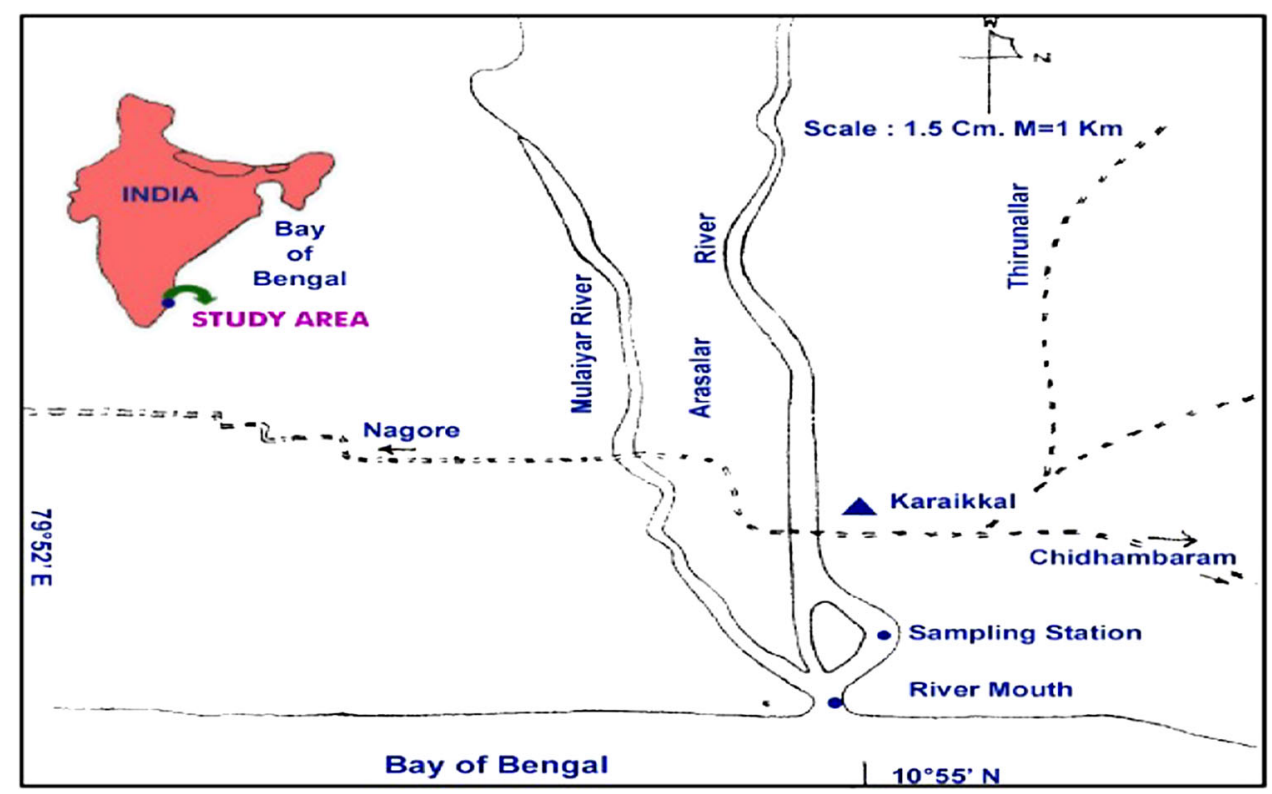


Table 1 Correlation coefficient $(r)$ values between the environmental parameters

\begin{tabular}{|c|c|c|c|c|c|c|c|c|}
\hline Parameters & At. temp. & W. temp. & $\mathrm{pH}$ & Salinity & DO & Silicate & Phosphorous & Nitrate \\
\hline At. temp. & 1 & & & & & & & \\
\hline W. temp. & 0.7618 & 1 & & & & & & \\
\hline $\mathrm{pH}$ & 0.8244 & 0.7918 & 1 & & & & & \\
\hline Salinity & 0.8396 & 0.714 & 0.88582 & 1 & & & & \\
\hline DO & -0.608 & -0.721 & -0.6831 & -0.6439 & 1 & & & \\
\hline Silicate & -0.745 & -0.639 & -0.7843 & -0.9036 & 0.8024 & 1 & & \\
\hline phosphorous & -0.647 & -0.781 & -0.6643 & -0.7924 & 0.765 & 0.8457 & 1 & \\
\hline Nitrate & -0.827 & -0.786 & -0.8295 & -0.9144 & 0.8518 & 0.9042 & 0.8356368 & 1 \\
\hline
\end{tabular}

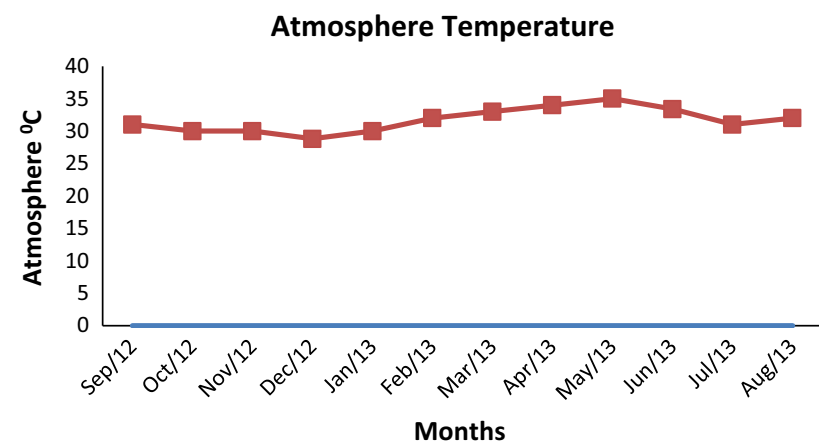

Fig. 2 Monthly variations of atmospheric temperature during September 2012-August 2013

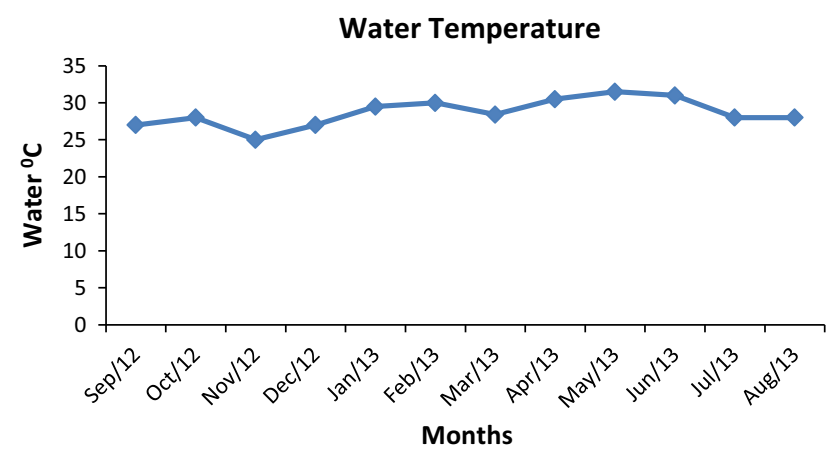

Fig. 3 Monthly variations of water temperature during September 2012-August 2013

recorded in the monsoon seasons (December 2012) Fig. 4. The Salinity in Arasalar estuary varied from 5.5 to $34 \%$. Minimum salinity (5.5\%) was recorded during monsoon (November 2012) and was slowly built up during postmonsoon, and attained maximum (34 \%o) during summer seasons (May 2013) Fig. 5. Dissolved oxygen in Arasalar estuary ranged from 3.5 to $7.2 \mathrm{ml} / \mathrm{l}$, while the Minimum DO was recorded during the month of June, 2013; maximum occurred in the month of November, (2012) Fig. 6. For dissolved phosphorus, the monthly values recorded in

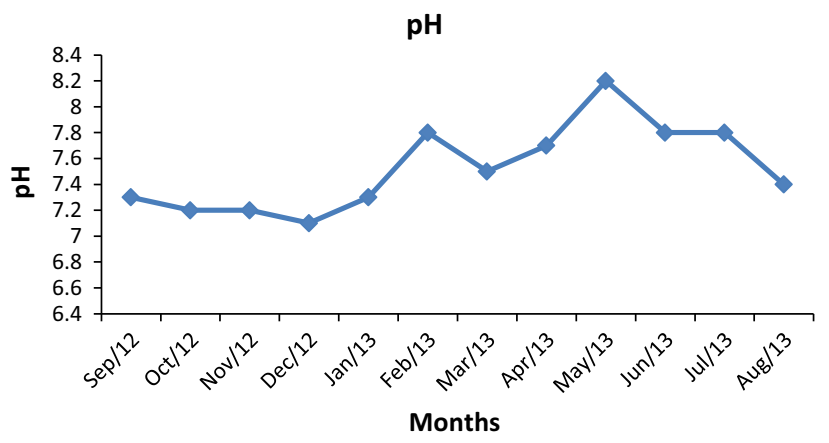

Fig. 4 Monthly variations of $\mathrm{pH}$ during September 2012-August 2013

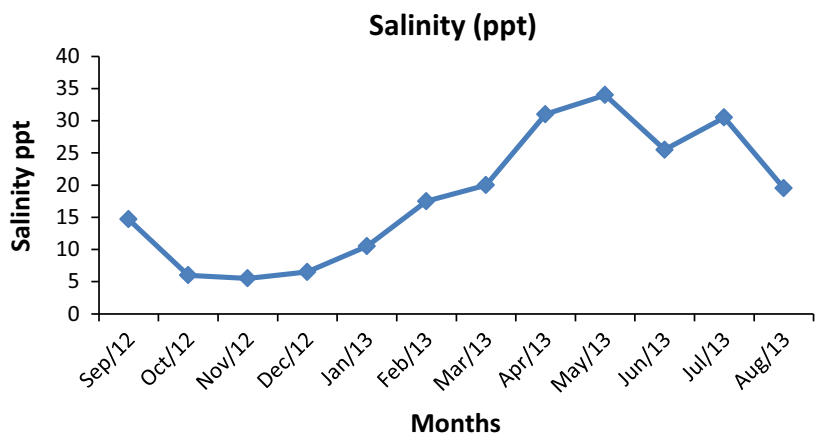

Fig. 5 Monthly variations of salinity during September 2012-August 2013

Arasalar estuary ranged from 0.29 to $2.15 \mu \mathrm{g} / \mathrm{l}$. The total phosphorus was minimum in the month of June, 2012 and maximum during the month of November, 2012 (Fig. 7). The nitrate varied from 0.49 to $3.75 \mu \mathrm{g} / \mathrm{l}$. Minimum was recorded during the month of June, 2013 and the maximum during the month of October 2012 Fig. 8. The monthly variation of silicate recorded in Arasalar estuary varied from 28.25 to $98.94 \mu \mathrm{g} / \mathrm{l}$. Minimum silicate was recorded during the month of May, 2013 and maximum during the month of November, 2012 Fig. 9. 


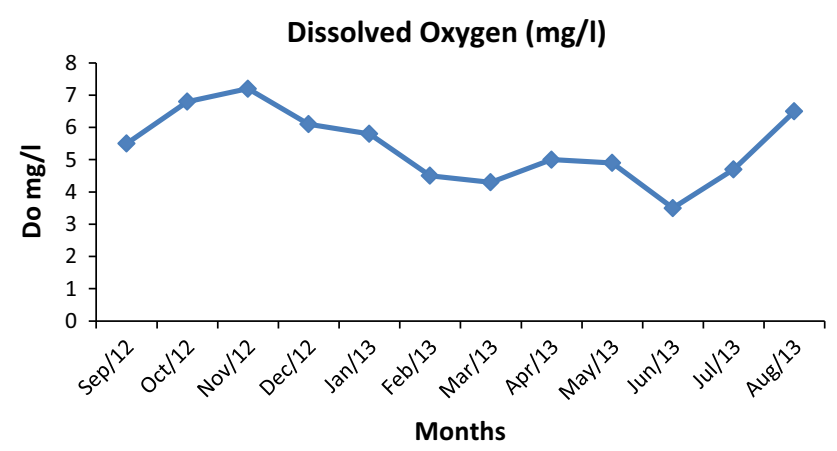

Fig. 6 Monthly variations of dissolved oxygen during September 2012-August 2013

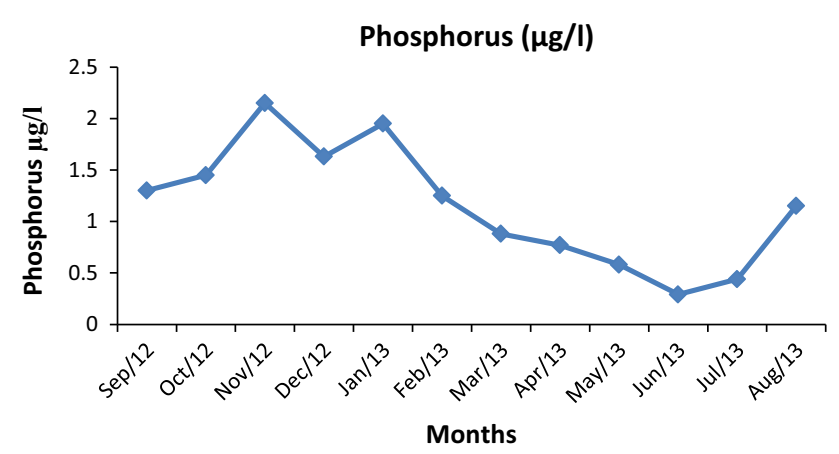

Fig. 7 Monthly variations of total phosphorus during September 2012-August 2013

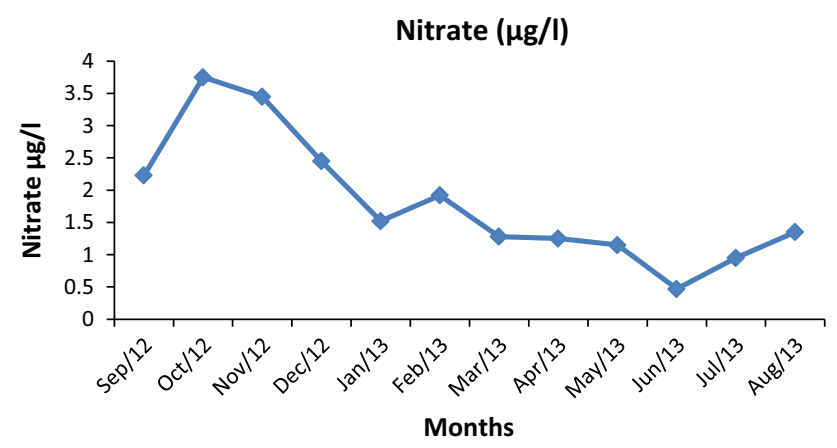

Fig. 8 Monthly variations of atmospheric temperature during September 2012- August 2013

Ichthyofauna diversity of Arasalar estuary

A total of 866 fishes were collected belonging to 4 orders and 5 families in the study area (Fig. 10). Mystus gulio accounted for about $25.40 \%$ and Liza parsia was the second dominating fish contributing $21.94 \%$ of the total. Mugil cephalus occupied the third rank with $20.20 \%$. Sillago sihama with $17.89 \%$, Chanos chanos with $6.69 \%$ and Oreochromis mossambicus with $7.85 \%$ ranking fourth, fifth and sixth species.
Silicate $(\mu \mathrm{g} / \mathrm{l})$

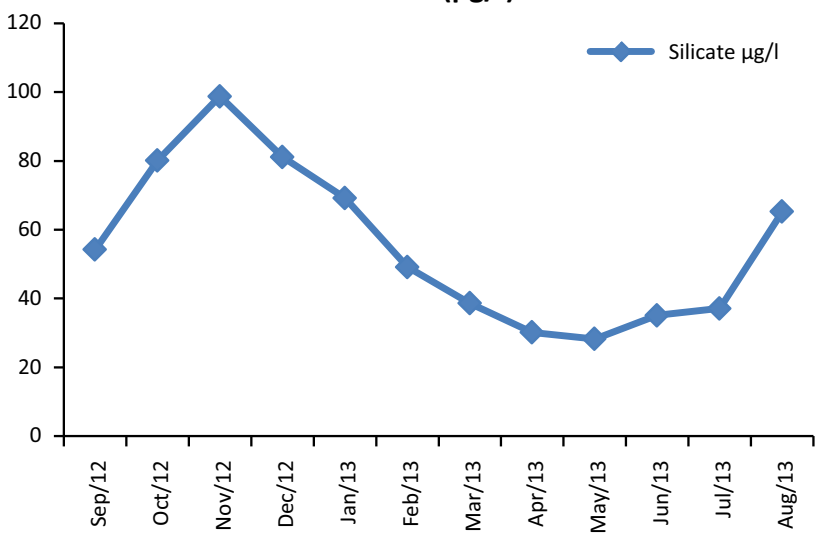

Fig. 9 Monthly variations of silicate during September 2012-August 2013

\section{Discussion}

The monthly variations in meteorological and physicochemical parameters such as, rainfall, air and surface water temperature, $\mathrm{pH}$, salinity, dissolved oxygen, phosphate, nitrate and silicate contents in Arasalar estuarine waters were recorded for a period of 1 year from September 2012 to August 2013. The surface water temperature largely depends upon the intensity of solar radiation, evaporation, freshwater influx, cooling and mixing due to currents and tidal flow. Surface water temperature also showed a similar trend of monthly variation as that of air temperature and the high values were reported during the summer season (May 2013) and lower values during the monsoon season (December 2012). The gradual increase in water temperature from monsoon to summer is directly related to atmospheric conduction and radiation. Similar findings were reported by (Thangaraj 1984). During the study period, air temperature varied from 28.8 to $35^{\circ} \mathrm{C}$. The minimum was recorded during monsoon season (December 2012) and maximum during the summer season (May 2013). Dissolved oxygen is one of the most important parameters, which reflects the physical and biological processes of water. The dissolved oxygen content depends upon the photosynthetic activities, monsoonal floods and the turbulence caused by winds (Nedumaran et al. 2011). In the present study, the dissolved oxygen concentration was low during summer and high during monsoon period. During 2012, the dissolved oxygen concentration was low compared to 2013, which may perhaps be due to low rainfall recorded during that period. The trend noticed in the present study is in accordance with the findings of hydrology and heavy metals (Rajasegar 2003). The seasonal variation of salinity in Arasalar estuary is graphically represented in Fig. 3. A marked seasonal change in salinity was observed throughout the study period. Minimum 
Fig. 10 Diversity of Ichthyofauna in Arasalar Estuary during September 2012-August 2013

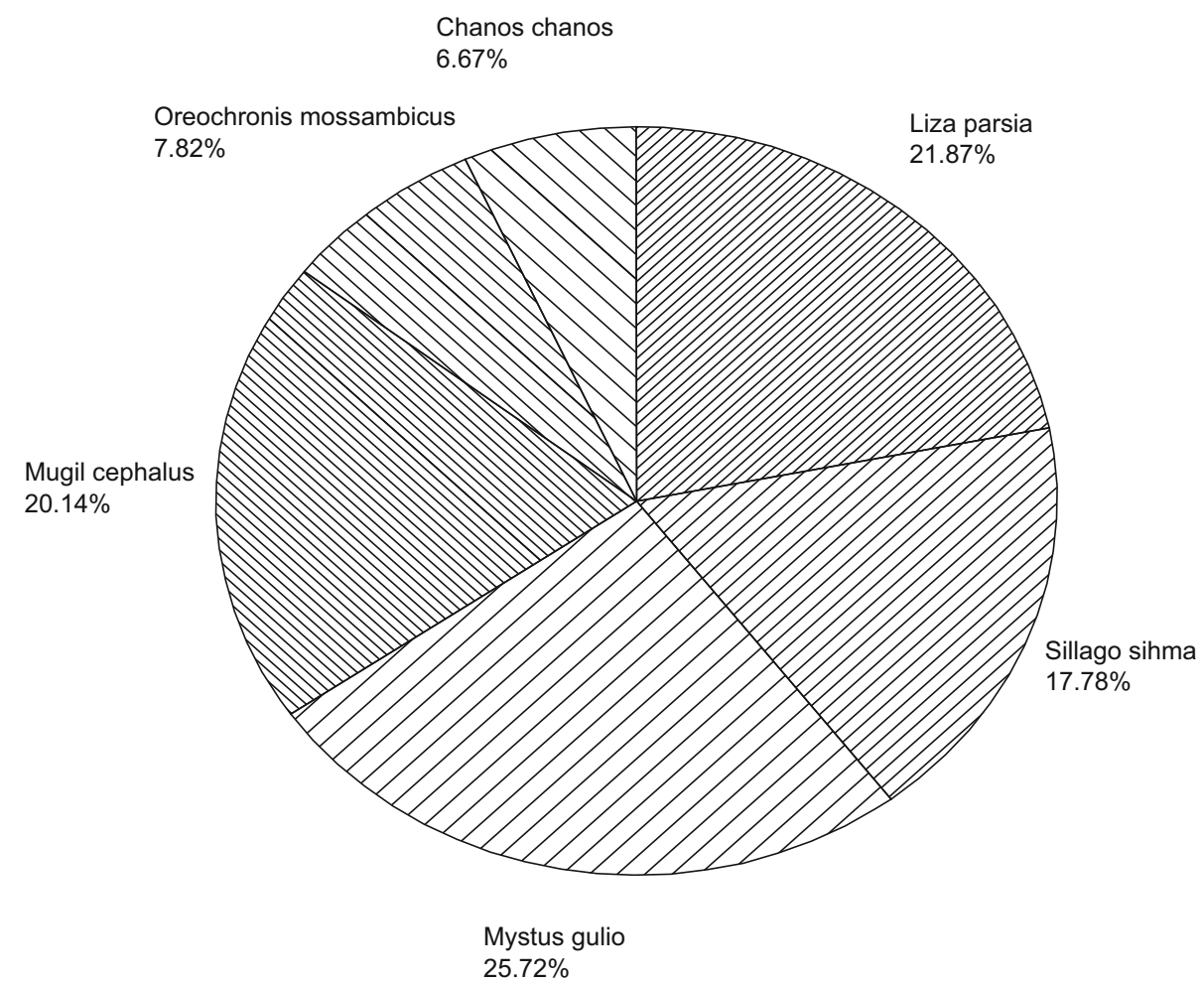

salinity was recorded during monsoon (December 2012) and increased slowly during post-monsoon, and attained maximum during summer seasons (May 2013). The salinity variation in the exchange of ions and nutrients is because of the tidal flow and low during the monsoon season in the Arasalar estuary. The present study is in conformity with the earlier reports from Vellar estuary (Palpandi 2011; Singbal 1976) and Uppanar backwaters (Murugan and Ayyakannu 1991; Soundarapandian et al. 2009). The monthly mean values of hydrogen ion concentration of water varied from 7.1 to 8.2. Maximum values of $\mathrm{pH}$ were observed in the summer season (May 2013) and minimum values were recorded in the monsoon seasons (December 2012). The minimum values of $\mathrm{pH}$ during monsoon in the study area may be controlled by the influence of freshwater discharge, rainfall and the decomposition of organic matter as stated by (Ragothaman and Patil 1995; Upadhyay 1998). The photosynthetic activity may cause high $\mathrm{pH}$, because of bicarbonate degradation by carbonic anhydrase associated with photosynthesis (Rajkumar et al. 2009). In the present study, the total phosphorus and nitrate were found to be higher during monsoon periods and decreased slowly from summer on wards. High concentration of total phosphorus during monsoon season due to heavy rainfall, decomposition of particulate organic matter, industrial effluents and from the agricultural discharges from the adjacent lands serious omissions. Such monsoonal maximum and summer minimum in the total phosphorus concentration were also reported from Vellar estuary (Chandran and Ramamoorthi 1984).

The peak values of silicate observed during monsoon may be attributed to the heavy fresh water influx and land run off which carries silt and other silicon deposits from upper the reaches of the river. Observations similar to present study were reported earlier by (Qasim et al. 1969; Ansari and Rajagopal 1974) in Cochin back waters (Nair et al. 1984) in Ashtamudi estuary (Prabha Devi 1986) in Coleroon estuary. The silicate concentration also showed negative relationship $(r=-0.9036)$ with salinity, which was also noted earlier in Vellar estuary (Chandran and Ramamoorthi 1984; Thangaraj 1984) and in Kerala backwaters (SaralaDevi et al. 1991). The diversity is an important tool to study a variety of species in a particular area and to evaluate the abundance of individuals within each species (Ramaiyan et al. 1986). In the present study, totally 866 fishes belonging to only five species were observed in the study area which may be due to the stable environmental condition at the study area. Similarly, high diversities were observed by (Morton 1989) in the Cochin waters and (Chandran 1982) in the Vellar estuary, and they attributed this is due to the stable environmental condition. The diversity values observed in the present study were comparable to the results of (Shanmugam 1985) in Vellar estuary and (Chandrasekaran 1986). The conclusion of the

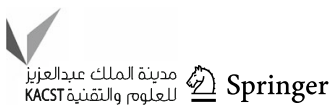


present study is that physico-chemical parameters influence the Ichthyofaunal diversity and Arasalar estuary are not extremely pollutant but at the same time there is a possibility of gradual addition of heavy metals in due course. It reveals that the estuarine environment is largely influenced by the annual cycle of monsoon.

Conflict of interest The author(s) have not declared any conflict of interests.

Open Access This article is distributed under the terms of the Creative Commons Attribution License which permits any use, distribution, and reproduction in any medium, provided the original author(s) and the source are credited.

\section{References}

Ansari SA, Rajagopal MD (1974) Distribution of mud phosphate in the Cochin backwater Mahasagar. Bull Natn Insts Oceanogr 7:69-72

Blaber SJM, Brew DT, Salini JP (1989) Species composition and biomass of fishes in different habitats of a tropical northern Australian estuary; their occurrence in the adjoin sea and estuarine dependence. East Coastal Self Sci 29:509-531

Chandran R (1982) Hydrobiological studies in the gradient zone of the Vellar estuary. Ph.D. Thesis Annamalai University, pp 95

Chandran R, Ramamoorthy K (1984) Hydrobiological studies in the gradient zone of Vellarestuary, Part-I: physico-chemical parameters. Mahasagar-Bull Natn Inst Oceanogr 17(3):133-140

Chandrasekaran V (1986) Studies on prawn and finfish seed resources of the Pichavaram mangrove region (Southeast Coast of India) Ph.D Thesis Annamalai University, pp 218

Day F (1889a) The fauna of British India including Ceylon and Burma. Fishes-I. Taylor and Francis, London, p 548

Day F (1889b) The fauna of British India, including Ceylon and Burma. Fishes-II. Taylor and Francis, London, p 509

Loneragon NR, Potter IC, Lenanton RCJ, Caputi N (1986) Saptial and seasonal differences in the fish fauna in the shallows of a large Australian estuary. Mar Biol 92:575-586

Morton RM (1989) Hydrology and fish fauna of canal developments in an intensively modified Australian Estuary. Estuar Coastal Shelf Sci 28(1):43-58

Moyle B, Robert A, Herbold Bruce, Donald M (1986) Patterns of distribution and abundance of a non coevolved assemblage of estuarine fishes in California. Fish Bull 84(1):105-118
Murugan A, Ayyakannu K (1991) Ecology of Uppanar backwaters, Cuddalore-II nutrients. Mahasagar-Bull Natl Inst Oceanogr 24(2):103-108

Nair NB, Abdul Azis PK, Dharmaraj K, Arunachalam M, Krishnakumar K, Balasubramanian NK (1984) Ecology of India estuaries: partV: primaryproductivity of Ashtumudi estuary, South West coast of India. Proc Indian Acad Sci Sci 93(1):2-23

Nelson JS (2006) Fishes of the World, 4th Edn. Wiley, p 624

Nedumaran TP, Perumal R, Rajaram (2011) Physico-chemical characteristic features of the Uppanar estuary, south east coast of India. J Ecotoxical Environ Monit 21(1):1-11

Palpandi P (2011) Hydrobiological parameters, pollution density and distribution pattern in the gastropod Nerita (dostia) crepidularia Lamarck, 1822, from mangroves of Vellar estuary, southeast India. Int J Biodvers Conserv 3(4):121-130

Prabha Devi L (1986) Hydrobiolgical studies in tidal zone of the Coleroon estuary. Ph.D Thesis, Annamalai University, p 241

Qasim SZ, Wellershaus S, Bhattathiri PMA, Abid SAH (1969) Organic production in a tropical estuary. Proc Indian Acad Sci 69B:51-94

Ragothaman G, Patil T (1995) Studies on the physico-chemical parameters and phytoplankton of Narmada estuary Enviromedia 14(2):221-226

Rajasegar M (2003) Physico-chemical characteristics of the vellar estuary in relation to shrimp farming. J Environ Biol 24:95-101

Rajkumar M, Perumal P, Ashok Prabu V, Vengadeshperumal N, ThillaiRajasekar K (2009) Phytoplankton diversity in Pichavaram mangrove waters from south-east coast of India. J Environ Biol 30:489-498

Ramaiyan V, Purushothaman A, Natarajan R (1986) Check list of estuarine and marine fishes of parangipettai (Porto Novo) Coastal waters. Matsya 12(13):1-19

SaralaDevi K, Sankaranrayanan VN, Venugopal P (1991) Distribution of nutrients in the Periyar river estuary. Indian J Mar Sci 20:49-54

Shanmugam S (1985) Studies on finfish and shellfish seed resources of the Vellar estuary (Southeast Coast of India). Ph.D. Thesis, Annamalai University India, pp 176

Singbal SYS (1976) Diurnal variation of some physico-chemical factors in the Mandovi estuary of Goa. Mahasagar 9:27-34

Soundarapandian P, Preamkumar T, Dinakaran GK (2009) Studies on the phyisco-chemical characteristics and nutrients in the Uppanar estuary of Cuddalore, south east coast of India. Curr Res J Biol Sci 1(3):102-105

Strickland JDH, Parson TR (1972) A practical hand book of seawater analysis. Bull Fish Res Bd Can 67:311

Thangaraj GS (1984) Ecology of the marine zone of Vellar estuary, Ph.D. Thesis, Annamalai University

Upadhyay S (1998) Physico-chemical characteristics of the Mahanadi estuarine ecosystem, east coast of India. Indian J Mar Sci 17:19-23 